\title{
ANALISIS TERHADAP MANAJEMEN DANA MUDHARABAH DALAM PERBANKAN SYARI'AH
}

\author{
Abdul Ghofur \\ Fakultas Syariah dan Hukum Universitas Islam Negeri Walisongo Semarang \\ Email: aghofur2009@gmail.com
}

\begin{abstract}
This study tried to the analyze practices mudharabah fund management in Islamic banking from the perspective of normative and philosophical. Mudharabah is interesting to examine, because the beginning of a substitute interest (riba) is the contract of profit sharing, one of which is based on mudharabah. Mudharabah is also rated as the contract representing equity in the transaction. However, in reality, the application of this mudharabah is not so simple, there are some problems inside it. The research found some results, among other things: First, the contract of mudharabah is one of contracts that is used by the Islamic bank to manage the funding and financing in order to avoid the practice of interest (riba). Second, ideally, mudharabah becone the mainstay products of Islamic banking, both in terms of funding or financing. Because, with the principle of partnership, the two parties are equally benefited. Thirdly, in fact, the bank and the customer will not want for various losses. While the mudharabah practice allows for this. Therefore, it requires tactical steps to minimize the impact of such losses. One of these steps is to conduct the training to prospective mudharib intensively for in terms of professionalism and confidence (trust) it. Further, it requires accompaniment for the candidate of capital manager (mudharib).
\end{abstract}

Keywords: mudharabah, justice, usury, the principle of partnership, trust

\begin{abstract}
Abstrak
Penelitian ini mencoba melihat praktek akad mudharabah di perbankan Syariah dari perspektif normatif dan filosofis. Akad mudharabah ini menarik untuk dikaji, sebab awal mula pengganti bunga (riba) adalah akad bagi hasil yang salah satunya didasarkan pada akad mudharabah ini. Akad mudharabah ini juga dinilai sebagai akad yang merepresentasikan keadilan dalam bertransaksi. Akan tetapi, dalam realitasnya, penerapan mudharabah ini tidak semudah yang dibayangkan, ada beberapa kendala di dalamnya. Dari hasil penelitian ditemukan beberapa hasil, antara lain: Pertama, akad Mudharabah merupakan salah satu akad yang dipergunakan oleh bank syari'ah untuk mengelola pendanaan dan pembiayaan dalam rangkan untuk menjauhi praktek bunga (riba). Kedua, akad mudharabah ini
\end{abstract}


sudah, idealnya, menjadi produk andalan perbankan syari'ah, baik dari segi pendanaan mauun pembiayaan. Sebab, dengan prinsip kemitraan di dalamnya, dua pihak yang bertransaksi sama-sama diuntungkan. Ketiga, dalam kenyataannya, pihak bank maupun nasabah tidak akan mau untuk berbagai kerugian. Sementara praktek mudharabah memungkinkan untuk hal tersebut. Oleh sebab itu, hal ini membutuhkan langkah-langkah taktis untuk meminimalisir dampak kerugian tersebut. Salah satu langkahnya adalah mengadakan pelatihan secara intensif kepada para calon mudharib secara intensif bagi dari segi profesionalitas maupun kepercayaan (trust)nya. Selanjutnya dibutuhkan pendampingan yang komprehenship terhadap pengelola modal (mudharib).

Kata Kunci: mudharabah, keadilan, riba, prinsip kemitraan, trust

\section{A. PENDAHULUAN}

Perbankan Syari'ah sekarang telah menjadi istilah yang terkenal luas baik di dunia Muslim maupun di dunia Barat. Istilah tersebut mewakili suatu bentuk perbankan dan pembiayaan yang berusaha menyediakan layanan-layanan bebas 'bunga' kepada para nasabah. Para pendukung perbankan syariah berpendapat bahwa bunga adalah riba dan karenanya menurut hukum Islam bunga bank diharamkan. Sikap terhadap bunga yang seperti itu mendorong beberapa sarjana dan praktisi perbankan muslim untuk menemukan sejumlah cara dan alat guna mengembangkan sistem perbankan alternatif yang sesuai dengan ajaran-ajaran hukum Islam, khususnya, aturan-aturan yang terkait dengan pengharaman riba.

Atas dasar ini perbankan syari'ah tidak menerima segala bentuk keuntungan yang ditetapkan terlebih dahulu atas modal dalam suatu traksaksi pinjam-meminjam/utang piutang. Untuk mempraktekkan teori ini, perbankan syari'ah harus menolak semua transaksi dan kontrak yang mengandung unsur bunga yang eksplisit. Namun, transaksi-transaksi yang unsur-unsur bunganya tidak eksplisit, atau dikenal dengan suatu nama yang selain dari bunga, dengan nama mudharabah, musyarakah, dan murabahah, sepenuhnya dapat diterima dengan istilah 'bagi hasil', 'upah', komisi, dan 'laba'.

Tulisan ini mencoba untuk menjelaskan bagaimana bank-bank syari'ah mengoperasionalkan dananya dalam rangka mendapatkan profit sebagaimana layaknya perbankan konvensional juga dalam upaya menjalankan pesan-pesan syariat yang di dalamnya sangat mengutuk 
praktek riba. Untuk memadukan keduanya dibutuhkan upaya-upaya tertentu baik dari segi kejelian memanage keuangannya maupun kecermatan dalam menerapkan pijakan hukum syare'atnya dalam hal ini adalah penerapan al-mudharabah.

\section{B. PENGERTIAN PERBANKAN SYARI'AH}

Kata bank berasal banque (Bahasa Perancis), dari Banco (bahasa Italia), yang berarti peti/lemari atau bangku yang fungsinya sebagai tempat menyimpan benda-benda berharga, seperti emas, berlian dan uang. ${ }^{1}$ Pada masa lalu para penukar uang (money changer) yang menyediakan jasanya untuk para pedagang di pelabuhan-pelabuhan meletakkan uang penukaran itu di atas banko (meja) di hadapan mereka. ${ }^{2}$ Namun seiring dengan perkembangan perdagangan dunia peranan perbankanpun juga berkembang. Dan istilah banko inilah yang pada era berikutnya dijadikan istilah yang digunakan untuk sebuah lembaga yang bergerak di bidang keuangan.

Menurut beberapa sumber, usaha perbankan ini dimulai dari zaman Babylonia dilanjutkan ke zaman Yunani Kuno dan Romawi. Tugas utama bank pada saat itu hanyalah sebagai tempat tukar menukar uang. Sejarah mencatat, bahwa perkembangan perbankan pada zaman kerajaan tempo dulu dimulai di daratan Eropa. Perkembangan perbankan di Asia, Afrika dan Amerika dibawa oleh bangsa Eropa pada saat melakukan penjajahan ke negara jajahannya baik di Asia, Afrika maupun benua Amerika. ${ }^{3}$

Aktivitas perbankan yang pertama adalah menghimpun dana dari masyarakat luas yang dikenal dengan istilah di dunia perbankan adala kegiatan funding. Pengertian menghimpun dana maksudnya adalah mengumpulkan atau mencari dana dengan cara membeli dari masyarakat luas. Pembelian dana dari masyarakat ini dilakukan oleh bank dengan cara memasang berbagai strategi agar masyarakat mau menanamkan dananya dalam bentuk simpanan. Jenis simpanan yang dipilih oleh masyarakat adalah seperti giro, tabungan, sertifikat deposito dan deposito berjangka.

1 M. Sholahuddin, SE, M.Si, Lembaga Ekonomi dan Kenangan Islam, Surakarta: Muhammadiyah University Press, 2006, hal. 13

${ }^{2}$ Fuad Muhammad Fachruddin, Riba dalam Bank, Koperasi dan Asuransi, Bandung: PT AlMa'arif, 1985, hal. 109

${ }^{3}$ Kasmir, SE, M.M, Bank dan Lembaga Kenangan Lainnya, Jakarta: PT Raja Grafindo Persada, 2002, hal. 27-28 
Setelah memperoleh dana dalam bentuk simpanan dari masyarakat, maka oleh perbankan dana tersebut diputar kembali atau dijual kembali ke masyarakat dalam bentuk pinjaman atau lebih dikenal dengan istilah kredit (lending). Dalam pemberian kredit juga dikenakan jasa pinjaman kepada penerima kredit (debitur) dalam bentuk bunga dan biaya administrasi. Sedangkan bagi bank yang berdasarkan prinsip syari'ah dapat berdasarkan bagi hasil atau penyertaan modal ${ }^{4}$

Menurut Undang-undang RI Nomor 10 tahun 1998 tanggal 10 November tentang perbankan, yang dimaksud dengan bank adalah "Badan usaha yang menghimpun dana dari masyarakat dalam bentuk simpanan dan meyalurkannya kepada masyarakat dalam bentuk kredit dan atau bentuk-bentuk lainnya dalam rangka meningkatkan taraf hidup rakyat banyak".

Sementara definisi bank syari'ah adalah bank yang beroperasi sesuai dengan prinsip-prinsip syari'ah Islam khususnya menyangkut tata cara bermuamalat secara Islam. Dalam tata cara bermuamalat tersebut dijauhi praktek-praktek yang dikhawatirkan mengandung unsur-unsur riba dan digantikan dengan kegiatan-kegiatan investasi atas dasar bagi hasil dan pembiayaan perdagangan. ${ }^{5}$

Definisi lain menjelaskan bahwa bank syari'ah adalah bank yang tata cara operasinya mengacu kepada ketentuan-ketentuan al-Qur'an dan AlSunnah. Artinya bank yang tata cara beroperasinya mengikuti suruhan dan larangan yang tercantum dalam al-Qur'an dan Hadits. Dengan demikian yang dijauhi adalah praktek-praktek yang mengandung unsur riba sedangkan yang dilakukan adalah praktek-praktek usaha yang dilakukan di zaman Rasulullah atau bentuk-bentuk usaha yang telah ada sebelumnya tetapi tidak dilarang oleh beliau. ${ }^{6}$

Dengan demikian, bank syari'ah adalah lembaga keuangan yang usaha pokoknya memberikan kredit dan jasa-jasa lain dalam lalu lintas pembayaran, serta peredaran uang yang beroperasi disesuaikan dengan prinsip-prinsip syari'at Islam. ${ }^{7}$ Atau dapat dijelaskan bahwa bank syari'ah

\footnotetext{
${ }^{4}$ Kasmir, SE, M.M, Bank dan Lembaga Kenangan Lainnya, Jakarta: PT RajaGrafindo Persada, 2002, hal. 23-24

${ }^{5}$ Drs. H. Karnaen Perwataatmadja, MPA, dan HH. Muhammad Syafi'I Antonio, M.Ec, Apa dan Bagaimana Bank Islam, Yogyakarta: PT Dana Bhakti Prima Yasa, 1992, hal. 1

${ }^{6}$ Ibid, hal. 2

${ }^{7}$ Heri Sudarsono, Bank dan Lembaga Kenangan Syari'ab: Deskripsi dan Ilustrasi, Yogyakarta: Ekonosia, 2003, hal. 12
} 
adalah bank yang beroperasi dengan tidak mengandalkan pada bunga, atau dengan kata lain merupakan lembaga keuangan/perbankan yang operasional dan produknya dikembangkan berdasarkan pada al-Qur'an dan Hadist Nabi SAW. Ini berarti operasi perbankan mengikuti tata cara usaha berdasarkan al-Qur'an dan Sunnah Rasul Muhammad SAW. ${ }^{8}$ Acuan bank syari'ah dalam beroperasi antara lain Al-Qur'an surat al-Baqarah: 275 tentang menjauhkan diri dari unsur riba dan diperbolehkannya sistem perdagangan.

"Orang-orang yang makan (mengambil) riba tidak dapat berdiri melainkan seperti berdirinya orang yang kemasukan syaitan lantaran (tekanan penyakit gila). Yang demikian itu adalah disebabkan mereka berkata (berpendapat): sesungguhnya jual beli itu sama dengan riba, padahal Allah telah menghalakan jual beli dan mengharamkan riba" (QS. Al-Baqarah: 275)

Teori Perbankan Syariah meneguhkan bahwa perbankan Syariah adalah perbankan bebas-bunga yang didasarkan pada konsep mudharabah dan musyarakah, yaitu, konsep Profit and Loss Sharing (PLS) atau "bagi hasil" (baik hasilnya keuntungan atau kerugian). Para Teoritisi perbankan dan fuqahaq Muslim yang menyumbangkan teori ini menafsirkan riba sebagai 'bunga' (interest) dan keuntungan yang telah ditentukan sebelumnya atas modal, khususnya modal uang. Mereka yakin bahwa penafsiran ulang atas definisi tradisional riba seperti yang dikembangkan dalam fiqh adalah tindakan yang jauh panggang dari api, mengingat akan ketidakberubahan dan kekekalan hukum-hukum Islam.

Dengan menafsirkan riba sebagai bunga, para teoritisi perbankan Islam menganut konsep awal bahwa setiap keuntungan yang ditambahkan atas pinjaman bagi pemberi pinjaman adalah riba. Berdasarkan pandangan ini, setiap penambahan (nominal atau riil) dalam suatu pinjaman yang diberikan kepada kreditur adalah riba. Diterimanya pandangan ini tidak akan mengizinkan bank syari'ah untuk menerima segala bentuk keuntungan yang ditetapkan terlebih dahulu atas modal dalam suatu traksaksi pinjam-meminjam/utang piutang. Untuk mempraktekkan teori ini, bank-bank Islam harus menolak, setidaknya secara teoritis, semua transaksi dan kontrak yang mengandung unsur bunga yang eksplisit

\footnotetext{
${ }^{8}$ Muhammad, Managemen Bank Syari'ah, Yogyakarta: UPP AMP YKPN, 2002, hal. 13

9 Departemen Agama RI, Al-Qur'an dan Terjemahannya, Yayasan Penyelenggara Penerjemahan Al-Qur'an, Semarang: CV Toha Putra, 1996, hal.69
} 
menurut suatu pengertian Ilegal. Jadi, transaksi-transaksi yang menggunakan bunga tetap maupun bunga tak tetap, obligasi-obligasi dan sebagainya harus ditolak.

Namun, transaksi-transaksi yang unsur-unsur bunganya tidak eksplisit, atau dikenal dengan suatu nama yang selain dari bunga, seperti dalam kasus opsi mata uang, kontrak-kontrak jual beli di depan, dan barter mata uang, operasi-operasi komersial jangka pendek dengan nama mudhaarabah, musyarakah, dan murabahah, sepenuhnya dapat diterima dengan istilah 'upah', komisi, dan 'laba'. Hal ini menjadi lengkap dengan memberikan penekanan lebih pada definisi legal atas kontrak dan transaksi, dan dengan menekankan pada makna literal teks-teks syari'ah yang terkait dengan masalah riba.

\section{MANAGEMEN DANA PERBANKAN SYARI'AH}

\section{Managemen Dana Perbankan}

Menurut Husein Umar, Managemen keuangan berfungsi dalam perencanaan organisasi untuk memperoleh dana, menggunakan dana dan sekaligus mengendalikan dana tersebut dalam rangka memaksimalisasi nilai oraganisasi. Secara skematik, konsep managemen keuangan dapat dilihat dalam skema sebagai berikut: ${ }^{10}$

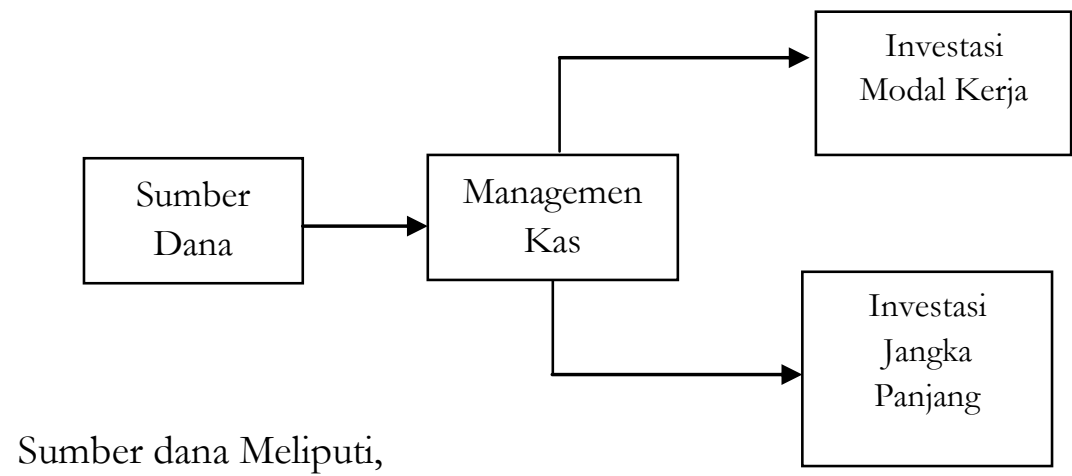

- Sumber Intern: laba, depresiasi, amortisasi

- Sumber Ekstern:

Pinjaman jangka pendek; Kredit Leveransir, Kredit rekening koran

- Pinjaman Jangka menengah; Kredit Modal Kerja Permanen, leasing

- Pinjaman Jangka panjang; Kredir Hipotek dan Obligasi

- Modal Sendiri; saham dan dividen

\footnotetext{
${ }^{10}$ Husein Umar, Research Methods in Finance and Banking, Jakarta: PT Gramedia Pustaka Utama, 2002, hal. 24
} 
Secara garis besar dalam managemen keuangan ini meliputi; (1) sumber dana (lihat penjelasan skema), (2) managemen Kas yang berupa managemen piutang dan managemen persediaan, (3) Investasi Modal kerja, dan (4) Investas jangka panjang. Dalam konteks managemen kas, ada beberapa metode pengumpulan dan sekaligus pengeluaran dana yang dapat membantu managemen agar lebih mampu meningkatkan efisiensi managemen kas. Metode-metode tersebut dimaksudkan agar perusahaan mampu mengumpulkan piutang secepat mungkin dan membayar utang selambat mungkin. Untuk menentukan kebijakan kredit yang optimal, misalnya, manager keuangan harus mempertimbangkan beberapa variable penting seperti; standar kredit, persyaratan kredit, dan usaha pengumpulan piutang.

Sedangkan managemen modal kerja berkepentingan terhadap keputusan investasi pada aktiva lancar dan utang lancar. Modal kerja diperlukan perusahaan untuk membiayai kegiatan operasional perusahaan. Perusahaan yang tidak mempunyai modal kerja yang cukup, tidak akan mampu membayar kewajiban jangka pendek tepat pada waktunya. Investasi modal kerja biasanya akan berputar kurang dari satu periode normal operasi perusahaan. Perusahaan perlu menjaga agar modal kerja tetap tersedia. Investasi untuk modal kerja seperti ini pada umumnya merupakan investasi untuk jangka pendek-menengah. ${ }^{11}$

\section{Prinsip-prinsip Managemen Dana Perbankan Syari'ah}

Bank adalah perantara keuangan masyarakat yaitu perantara dari mereka yang kelebihan uang dengan mereka yang kekurangan uang. Jadi, bagaimana bank melayani sebaik-baiknya mereka yang kelebihan uang dan menyimpan uangnya dalam bentuk giro, deposito dan tabungan serta melayani kebutuhan uang masyarakat melalui pemberian kredit. $^{12}$

Sementara menurut Husein Umar, bank memiliki tiga fungsi yang memberikan sumbangan kepada dunia usaha. Fungsi-fungsi itu adalah simpanan dana, kredit dan pembayaran. Untuk fungsi simpanan ini terkait dengan pertambahan uang yang beredar di masyarakat. Agar proses pengumpulan dana masyarakat berjalan sesuai dengan rencana managemen bank konvensional, maka dapat dilakukan melalui berbagai

\footnotetext{
11 ibid, hal. 27

${ }^{12}$ Muchdarsyah Sinungan, Managemen Dana Bank, Jakarta: PT Bumi Aksara, 2000, hal. 79
} 
produk tabungan yang menarik seperti pemberian bunga yang tinggi, hadiah yang cukup berharga, sampai pada rasa aman dan aspek manfaat dari bank tersebut.

Untuk fungsi kredit, perbankan akan menyediakan dana untuk masyarakat pengusaha, dalam rangka membantu penyediaan biaya untuk usahanya. Kredit itu sendiri mempunyai bentuk dan variasi Al-Qur'an surat al-Baqarah: 275 tentang menjauhkan diri dari unsur riba dan diperbolehkannya sistem perdagangan.

"Orang-orang yang makan (mengambil) riba tidak dapat berdiri melainkan seperti berdirinya orang yang kemasukan syaitan lantaran (tekanan penyakit gila). Yang demikian itu adalab disebabkan mereka berkata (berpendapat): sesunggubnya jual beli itu sama dengan riba, padahal Allah telah menghalakan jual beli dan mengharamkan riba" (QS. Al-Baqarah: 275) ${ }^{13}$

Penolakan atas bunga ini memunculkan pertanyaan tentang apa yang dapat menggantikan mekanisme penerapan suku bunga dalam sebuah kerangka kerja Islam. Managemen perbankan syari'ah, pada dasarnya memiliki beberapa jenis transaksi yang diaplikasikan dalam perbankan syari'ah untuk menggantikan peran suku bunga tersebut.

Pada dasarnya bank syari'ah mempunyai fungsi yang berbeda dengan bank konvensional yang cenderung mengandalkan bunga sebagai upaya untuk mendapatkan profit (keuntungan). Sementara bank syari'ah berperan sebagai manager investasi dari para pemilik dana (shabibul mal), sebab besar kecilnya pendapatan yang diterima oleh pemilik dana sangat tergantung pada pendapatan yang diterima oleh bank syari'ah dalam mengelola dana yang telah dihimpunnya. Dengan demikian, maka sangat tergantung pada keahlian, kehati-hatian, dan profesionalisme dari bank syari'ah tersebut.

Jika bank syari'ah dapat menghimpun dana yang besar, maka tidak serta merta akan mendapatkan hasil yang besar pula ketika dapat menyalurkan kepada para debitur. Sebab, apabila penyaluran dana tersebut tidak dilakukan tidak efektif, kurang memperhatikan kehatihatian, banyak yang macet atau banyak yang dikategorikan dalam non performing, banyak yang tidak melakukan pembayaran angsuran, maka

13 Departemen Agama RI, Al-Qur'an dan Terjemahannya, Yayasan Penyelenggara Penerjemahan Al-Qur'an, Semarang: CV Toha Putra, 1996, hal.69 
hal ini akan membawa dampak pendapatan yang diikuti aliran kas masuk (cash basis) yang hanya sedikit diterima.

Dengan adanya pendapatan yang cash basisnya sedikit, maka pendapatan yang akan dibagi antara bank syari'ah dan shobibul mal juga sedikit. Dan ini akan membawa dampak kecilnya pendapatan yang diterima oleh shabibul mal dan ini akan mempengaruhi tingkat kepercayaan nasabah (shabibul mal) untuk menitipkan uangnya di bank syari'ah. Namun sebaliknya, penyaluran dana yang dilakukan secara efektif, efisien, dan produktif sehingga banyak debitur yang melakukan pembayaran angsuran atau pembayaran bagi hasil maka akan membawa dampak pada pendapatan yang akan dibagi antara bank syari'ah dan nasabah (shabibul ma). Dan inilah sebetulnya perbedaan prinsip antara perbankan konvensional dan perbankan syari'ah.

Dengan melihat penjelasan di atas maka secara umum operasional perbankan syari'ah dalam kaitannya dengan managemen dana secara makro adalah sebagaimana tercermin dalam gambar berikut: ${ }^{14}$

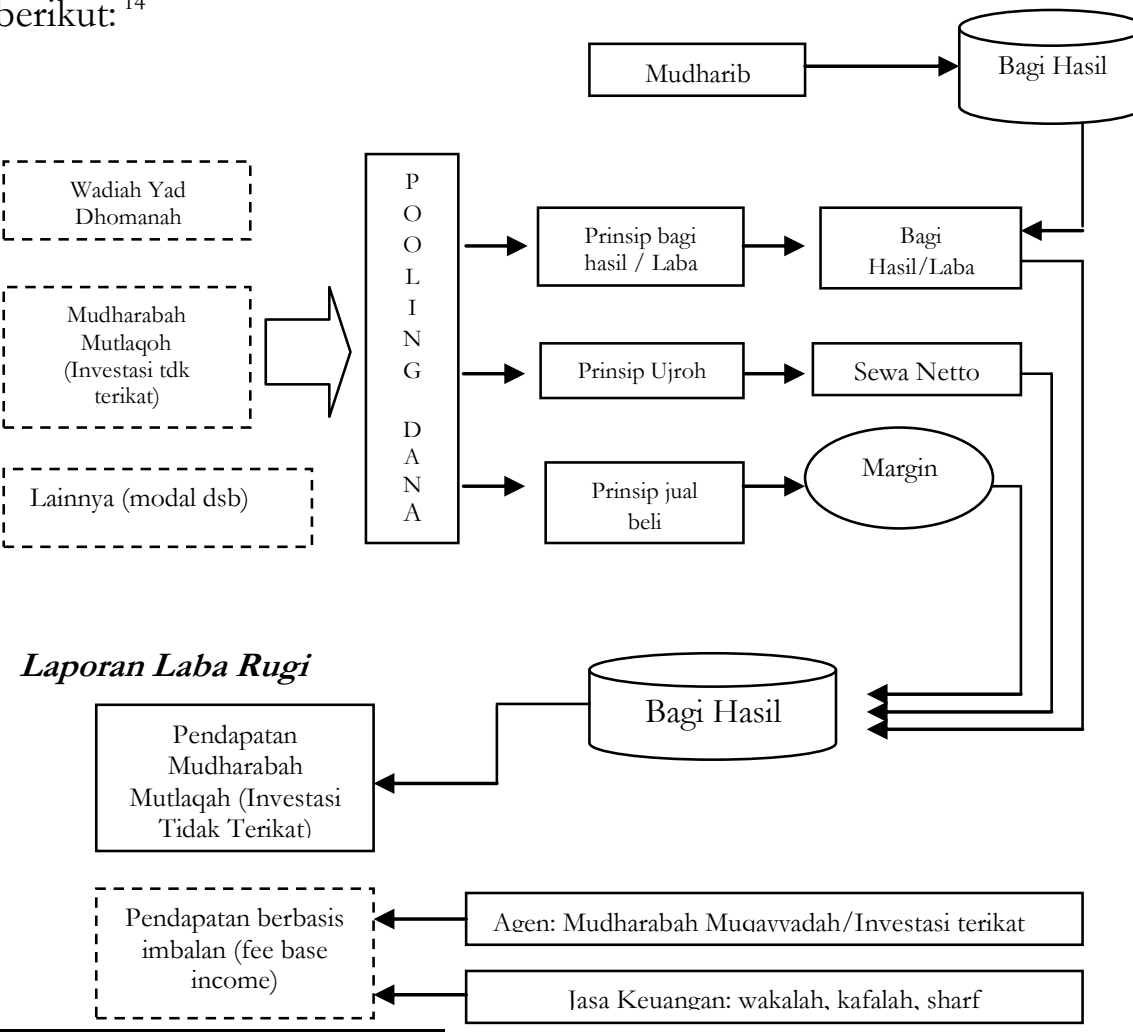

14 Wiroso, SE, MBA, Penghimpunan Dana dan Distribusi Hasil Usaha Bank Syari'ah, Jakarta: PT Gramedia, 2005, hal. 12 


\section{MUDHARABAH DALAM NORMATIVITAS HUKUM ISLAM DAN PRAKTEK PERBANKAN}

Istilah "mudharabah" merupakan istilah yang paling banyak digunakan oleh bank-bank Islam. Prinsip ini juga dikenal sebagai "qiradh" atau "muqaradhah". Mudharabah disebut juga qiradh yang berarti "memutuskan". Dalam hal ini, si pemilik uang itu telah memutuskan untuk menyerahkan sejumlah uangnya untuk dikelola oleh mudharib dan memutuskan sebagian dari keuntungannya bagi kedua orang yang terlibat akad qiradh ini. ${ }^{15}$ Mudharabah adalah kontrak antara dua pihak di mana satu pihak yang disebut rab al-mal (investor) mempercayakan uang kepada pihak kedua yang disebut mudharib untuk tujuan menjalankan usaha dagang. Mudharib menyumbangkan tenaga dan waktunya serta mengelola kongsi mereka sesuai dengan syaratsyarat kontrak. Keuntungan hasil usaha dibagikan sesuai dengan nisbah porsi bagi hasil yang telah disepakati bersama.

Dalam terminologi hukum, mudharabah adalah suatu kontrak di mana suatu kekayaan (property) atau persediaan (stock) tertentu ditawarkan oleh pemiliknya kepada pihak lain untuk membentuk suatu kemitraan (joint partnership) yang di antara kedua pihak dalam kemitraan itu akan berbagi keuntungan. Pihak lain yang berhak untuk memperoleh keuntungan karena kerjanya mengelola kekayaan tersebut disebut mudharib. ${ }^{16}$

Tujuan akad mudharabah adalah supaya ada kerjasama kemitraan antara pemilik harta (modal) yang tidak memiliki pengalaman dalam perniagaan/perusahaan atau tidak peluang untuk berusaha sendiri dengan orang yang berpengalaman di bidang tersebut tetapi tidak memiliki modal. Ini merupakan suatu langkah untuk menghindari menyia-nyiakan modal pemilik harta dan menyia-nyiakan keahlian tenaga ahli yang tidak mempunyai modal untuk memanfaatkan keahlian mereka. ${ }^{17}$

landasan syari'ah yang digunakan oleh perbankan syari'ah dalam rangka mengumpulkan dana dengan akad mudharabah, antara lain:

\footnotetext{
${ }^{15}$ Rachmat Syafei, Prof. Dr. H. M.A, Fiqh Muamalah, Bandung: Pustaka Setia, 2001, hal. 223

16 Sutan Remy Sjahdeini, Perbankan Syariab; Produk-produk dan Aspek-aspek Hukumnya, Jakarta: Kencana Prenadamedia Group, 2014, hal. 292

17 Wiroso, SE, M.B.A, Penghimpunan Dana dan Distribusi Hasil Usaha Bank Syariah, Jakarta: Grasindo, 2005, hal. 34
} 
1) QS. Al-Nisa' ayat 29

ياايها الذين امنوا لاتأكلو المو الكم بينكم بالباطل الآ ان تكون تجارة عن تر اض

منكم

"Hai orang yang beriman! Janganlah kalian saling memakan (mengambil) harta sesamamu dengan jalan yang batil, kecuali dengan jalan perniagaan yang berlaku dengan sukearela di antaramu..."

2) QS. Al-Muzammil ayat 20:

ـ....

"...Dan orang-orang yang berjalan di muka bumi mencari sebagian karunia Allah..."

3) QS. Al-Jumu'ah ayat 10

فاذا قضيت الصلوة فا نتشروا في الارض و ابتغوا من فضل الله ....

"Apabila telah ditunaikean shalat maka bertebaranlah kamu di muka bumi dan crilah Kearunia Allab Swt ..."

4) QS. Al-Ma'idah (5) ayat 1

"Hai orang-orang beriman! Penubilah akad-akad itu.."

5) QS. Al-Baqarah (2) ayat 283

$$
\text { ... فان امن بعضكم بعضا فليؤد الذى اؤتمن امانته وليتق الله ربه ... }
$$

"Maka, jika sebagian kamu mempercayai sebagian yang lain, hendaklah yang dipercayai itu menunaikan amanatnya dan hendaklah ia bertaqwa kepada Allah Tubannya.."

6) Hadits Nabi riwayat Thabrani:

روى ابن عباس رضى الله عنهما انه قال كان سيدنا العباس بن عبد المطلب اذا

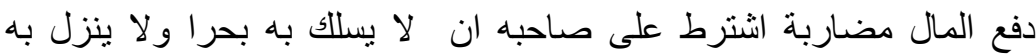

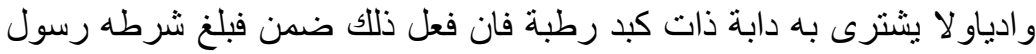

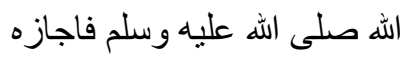

"Diriwayatkan dari Ibnu Abbas babwa Saiyyidina Abbas bin Abdul Muthalib jika memberikan dana ke mitra usahanya secara mudharabah ia mensyaratkan agar dananya tidak dibawa mengarungi lautan, menuruni lembah yang berbahaya, atau membeli ternak. Jika menyalahi peraturan tersebut, yang bersangkutan bertanggung jawab atas dana tersebut. Disampaikanlah syarat-syarat tersebut kepada Rasulullah saw. dan beliau membolebkannya” (HR. Thabrani)

Disamping itu para fuqaha juga bersandar pada preseden dari perjanjian mudharabah sebagai System penitipan modal yang dikelola Nabi SAW tatkala beliau dipercaya membawa sebagian barang dagangan Siti Khatijah r.a. sebelum pernikahan mereka, dari Makkah ke Negeri Syam (Syiria). Barang tersebut dianggap sebagai modal usaha, 
karena oleh Nabi SAW. dijual dan hasilnya dibelikan barang dagangan lainnya untuk dijual lagi di pasar Bushra di negeri Syam. Setelah beberapa lama, nabi kembali ke Mekkah dengan membawa hasil usahanya dan dilaporkan kepada Siti Khatijah r.a. Harta yang telah dikembangkan itu dihitung dan dibandingkan dengan harta semula. Harta semula dikembalikan kepada yang empunya (shabibul mal), sedang selisihnya antara shabibul mal dengan yang mengelola (mudharib) sesuai dengan kesepakatan di awal. Mudharib mendapatkan bagian karena telah melakukan perjalanan (dharb) untuk mencari sebagian karunia Allah. ${ }^{18}$

Akad mudharabah ini dipergunakan oleh perbankan syari'ah dalam rangka menghimpun dana, di mana penyimpan bertindak sebagai shabibul mal (pemilik modal) dan bank sebagai mudharib (pengelola). Pendapatan atau keuntungan tersebut dibagi berdasarkan nisbah yang telah disepakati diawal akad. Dana nasabah yang telah disimpan di bank akan dikelola oleh bank untuk mendapatkan keuntungan. Hasil pengelolaannya dibagikan antara bank dan nasabah.

Mudharabah ini biasanya diterapkan pada produk-produk pembiayaan dan pendanaan. Pada sisi penghimpunan dana, almudharabah diterapkan pada:

1. tabungan berjangka, yaitu tabungan yang dimaksudkan untuk tujuan khusus, seperti tabungan haji, tabungan qurban dan deposito biasa.

2. Deposito special (special investment), di mana dana yang dititipkan nasabah khusus untuk bisnis tertentu, misalnya murabahah saja atau ijarah saja.

Secara umum aplikasi penghimpunan dana/keuangan dengan prinsip mudharabah dapat dilihat sebagaimana skema berikut:

1. Titip Dana

2. Pemanfaatan dana

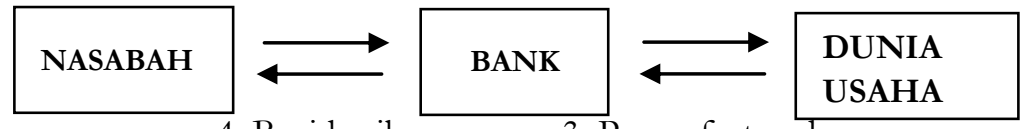

4. Bagi hasil 3. Pemanfaatan dana

Adapun aplikasi pembiayaan mudharabah diterapkan untuk (1) pembiayaan modal kerja, seperti modal kerja perdagangan dan jasa (2) Investasi khusus, disebut juga mudharabah muqayyadah, di mana sumber

18 Widyaningsih, SH (Ed.), Bank dan Asuransi Islam di Indonesia, Jakarta: Kencana, 2005, hal. 20 
dana khusus dengan penyaluran yang khusus dengan syarat-syarat yang telah ditetapkan oleh shahibul mal.

Secara umum aplikasi mudharabah dalam dunia perbankan dapat digambarkan dalam skema berikut:

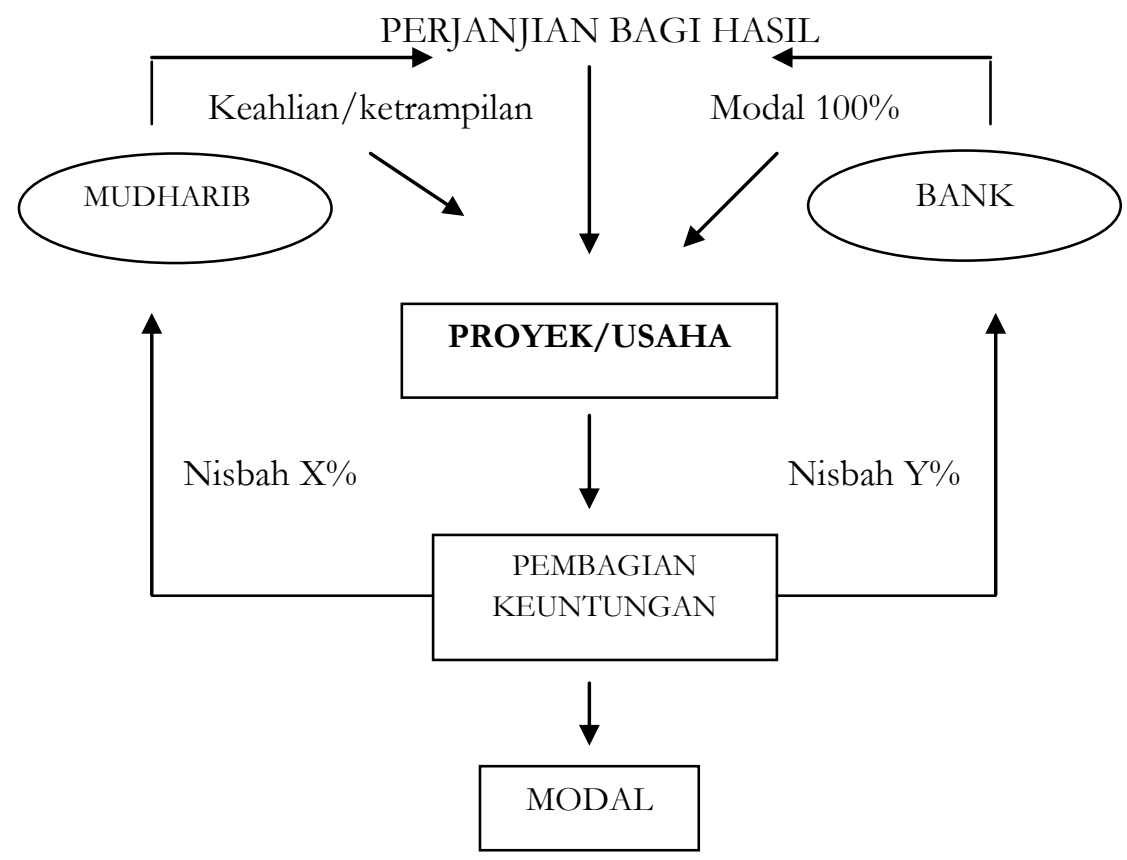

\section{E. ANALISIS TERHADAP MANAGEMEN DANA MUDHARABAH DALAM PRAKTEK PERBANKAN SYARI'AH}

Penerapan distribusi hasil usaha dengan prinsip bagi untung (profir sharing) dalam mudharabah bukanlah yang mudah, karena dalam pelaksanaannya sangat diperlukan adanya mekanisme kerja yang baik dan kesiapan semua pihak. Pihak deposan harus siap menerima bagian kerugian apabila pengelolaan dana mudharabah mengalami kerugian yang bukan akibat dari kelalaian mudharib, sehingga uang yang diinvestasikan oleh bank syari'ah menjadi berkurang dan ini jelas akan mengurangi kepercayaan masyarakat untuk berinvestasi di bank syari'ah.

Di lain pihak, bank syari'ah harus secara jujur dan transparan menyampaikan beban-beban yang akan ditanggung dalam pengelolaan dana mudharabah. Selain itu, bank syariah juga harus tertib administrasi sehingga tidak ada kesalahan dalam pengadministrasian dan dalam 
penghitungan unsur-unsur distribusi hasil usaha yang dapat berakibat adanya kesalahan perhitungan hasil usaha yang diberikan kepada shabibul mal.

Apabila bank syari'ah menerapkan pembiayaan hasil usaha berdasarkan prinsip bagi untung (profit sharing), bank syari'ah harus membuat dua laporan laba rugi secara terpisah, yaitu laporan laba rugi bank sebagai institusi keuangan sendiri dan laporan pengelolaan dana mudharabah di mana bank sebagai mudharib (pengelola dana). Dalam laporan laba rugi bank sebagai pengelola dana mudharabah, keuntungan (pendapatan dikurangi dengan beban-beban) atas pengelolaan dana mudharabah inilah yang akan dipergunakan sebagai dasar dalam perhitungan distribusi hasil usaha, dan apabila pengelolaan tersebut mengalami kerugian dan bukan karena kelalaian mudharib (bank) maka kerugian tersebut langsung dibebankan kepada shabibul mal.

Dalam kenyataannya lembaga keuangan syari'ah di Indonesia belum ada yang menjalankan bagi untung (profi sharing) apalagi bagi utang (loss sharing) dalam menjalankan distribusi hasil usaha antara shahibul mal dan mudharib. Hampir semua Bank syari'ah cenderung mempergunakan prinsip bagi hasil (revenue sharing) ${ }^{19}$ Prinsip revenue sharing diterapkan berdasarkan pendapat al-syafi'i yang mengatakan bahwa mudharib tidak boleh menggunakan harta mudharabah sebagai biaya, baik dalam keadaan menetap maupun bepergian. Yang menjadi masalah adalah ketika bank syari'ah berperan sebagai shabibul mal, apakah pihak mudharib akan menggunakan profit sharing atau revebue sharing. Dan ini akan berimplikasi pada distribusi pembagian hasil usaha.

Adapun contoh penghitungan pembiayaan mudharabab adalah sebagai berikut: Muhammad Amin mengajukan pembiayaan untuk modal kerja dagang sebesar Rp. 100 juta selama 1 tahun, dengan perbandingan bagi hasil nasabah dan bank 60:40. Dalam aplikasi perbankan, cara untuk mengembalikan modal dan melakukan bagi hasil ada dua kemungkinan: ${ }^{20}$

\footnotetext{
${ }^{19}$ Wiroso, SE, MBA, Penghimpunan Dana dan Distribusi Hasil Usaba Bank Syari'ah, Jakarta: PT Grasindo, 2005, hal. 120. Berdasarkan wawancara penulis dengan Bapak Akhmad Nuruddin Kepala Kas Bank Syari'ah Mandiri (BSM) Cabang Ngaliyan, bagi hasil yang digunakan BSM adalah revenue sharing.

${ }^{20}$ Muhammad Syafi'I Antonio, Bank Syari'ah Wacana Ulam dan Cendekiawan, hal. 183
} 
Model Cicilan I

\begin{tabular}{|c|c|c|c|c|c|}
\hline BLN & $\begin{array}{l}\text { HASIL } \\
\text { USAHA }\end{array}$ & $\begin{array}{c}\text { BAGIAN } \\
\text { BANK }\end{array}$ & $\begin{array}{c}\text { BAGIAN } \\
\text { NASABAH }\end{array}$ & $\begin{array}{c}\text { CICILAN } \\
\text { POKOK }\end{array}$ & $\begin{array}{c}\text { TOTAL } \\
\text { SETORAN }\end{array}$ \\
\hline & & $40 \%$ & $60 \%$ & & \\
\hline 1. & 6.000 .000 & 2.400 .000 & 3.600 .000 & - & 3.600 .000 \\
\hline 2. & 7.000 .000 & 2.800 .000 & 4.200 .000 & - & 4.200 .000 \\
\hline 3. & 4.000 .000 & 1.600 .000 & 2.400 .000 & - & 2.400 .000 \\
\hline 4. & 4.500 .000 & 1.800 .000 & 2.700 .000 & - & 2.700 .000 \\
\hline 5. & 5.000 .000 & 2.000 .000 & 3.000 .000 & - & 3.000 .000 \\
\hline 6. & 5.500 .000 & 2.200 .000 & 3.300 .000 & - & 3.300 .000 \\
\hline 7. & 6.000 .000 & 2.400 .000 & 3.600 .000 & - & 3.600 .000 \\
\hline 8. & 5.400 .000 & 2.160 .000 & 3.240 .000 & - & 3.240 .000 \\
\hline 9. & 9.000 .000 & 3.600 .000 & 5.400 .000 & - & 5.400 .000 \\
\hline 10. & 5.700 .000 & 2.280 .000 & 3.420 .000 & - & 3.420 .000 \\
\hline 11. & 4.700 .000 & 1.880 .000 & 2.820 .000 & - & 2.820 .000 \\
\hline 12. & 3.500 .000 & 1.400 .000 & 2.100 .000 & - & 102.100 .000 \\
\hline Total & 66.300 .000 & 26.220 .000 & 39.780 .000 & - & 139.780 .000 \\
\hline
\end{tabular}

Model Cicilan II

\begin{tabular}{|c|c|c|c|c|c|c|}
\hline BLN & $\begin{array}{l}\text { HASIL } \\
\text { USAHA }\end{array}$ & $\begin{array}{c}\text { HASIL } \\
\text { USAHA YG } \\
\text { DIBAGIKA } \\
\text { N }\end{array}$ & $\begin{array}{c}\text { BAGIAN } \\
\text { BANK }\end{array}$ & $\begin{array}{c}\text { BAGIAN } \\
\text { NASABAH }\end{array}$ & $\begin{array}{c}\text { CICILAN } \\
\text { РОКОK }\end{array}$ & $\begin{array}{c}\text { TOTAL } \\
\text { SETORA } \\
\mathbf{N}\end{array}$ \\
\hline & & & $40 \%$ & $60 \%$ & & \\
\hline 1. & 6.000 .000 & 6.000 .000 & 2.400 .000 & 3.600 .000 & 8.500 .000 & 10.900 .000 \\
\hline 2. & 7.000 .000 & 6.405 .000 & 2.562 .000 & 3.842 .000 & 8.500 .000 & 11.062 .000 \\
\hline 3. & 4.000 .000 & 3.320 .000 & 1.328 .000 & 1.992 .000 & 8.500 .000 & 9.828 .000 \\
\hline 4. & 4.500 .000 & 3.352 .500 & 1.341 .000 & 2.011 .500 & 8.500 .000 & 9.841 .000 \\
\hline 5. & 5.000 .000 & 3.300 .000 & 1.320 .000 & 1.980 .000 & 8.500 .000 & 9.820 .000 \\
\hline 6. & 5.500 .000 & 3.162 .500 & 1.265 .000 & 1.897 .000 & 8.500 .000 & 9.765 .000 \\
\hline 7. & 6.000 .000 & 2.940 .000 & 1.176 .000 & 1.764 .000 & 8.500 .000 & 9.676 .000 \\
\hline 8. & 5.400 .000 & 2.187 .000 & 847.800 & 1.312 .000 & 8.500 .000 & 9.374 .800 \\
\hline 9. & 9.000 .000 & 2.880 .000 & 1.152 .000 & 1.728 .000 & 8.500 .000 & 9.652 .000 \\
\hline 10. & 5.700 .000 & 1.339 .000 & 535.800 & 803.700 & 8.500 .000 & 9.035 .000 \\
\hline 11. & 4.700 .000 & 705.000 & 282.000 & 423.000 & 8.500 .000 & 8.782 .000 \\
\hline 12. & 3.500 .000 & 227.500 & 91.000 & 136.500 & 6.500 .000 & 6.591 .000 \\
\hline Jumlah & 66.300 .000 & 35.819 .000 & 14.327 .600 & 21.491 .000 & 100.000 .000 & 114.327 .000 \\
\hline
\end{tabular}

Dari penghitungan di atas kita dapat melihat bahwa untuk teknis pengembalian modal pada model yang pertama secara hukum Islam tidak masalah, sebab dana yang dioperasionalkan masih berada di tangan pengelola (mudharib). Meskipun masih menyisakan pertanyaan apakah 
dalam pembagian hasilnya itu menggunakan profit sharing atau revenue sharing. Artinya ketika akad dilakukan bank syari'ah harus memberi gambaran dan memilih secara tegas mana di antara keduanya yang dipergunakan.

Sementara cara penghitungan kedua ada sesuatu yang harus dipertanyakan terutama mengenai pengembalian modal secara bertahap. Apakah yang pembagian hasil itu dari seluruh pembiayaan yang telah diterima oleh mudharib atau dari sisanya. Berikutnya, cara penghitungan hasil usaha yang demikian, jelas membutuhkan kecermatan sendiri. Atas dasar berbagai pertimbangan kendala di atas, maka tidak heran jika sebagian masyarakat berpendapat bahwa managemen perbankan syari'ah cenderung mengadopsi produk-produk perbankan konvensional yang "disyari'ahkan" dengan variasi produk dan cara perhitungan hasil usaha yang disesuaikan.

Aplikasi akad-akad dalam perbankan syari'ah pada dasarnya adalah untuk menjawab pertanyaan besar mengenai operasionalisasi perbankan yang bebas bunga (riba) yang dinilai oleh banyak kalangan tidak mampu untuk menyejahterakan masyarakat lemah dan cenderung 'membela' pemilik modal (kapital). Oleh sebab itu, perlu perjuangan tersendiri untuk terciptanya sebuah Sistem perbankan yang non-ribawi baik secara literal, fungsional dan social. Pemberlakuan Bunga dalam bank konvensional yang dinilai identik dengan riba, telah menyadarkan bagi para pegiat ekonomi syariah untuk menciptakan sistem keuangan yang bebas bunga, dan pilihan utamanya adalah bagi hasil yang bertumpu pada akad mudharabah. Oleh sebab, tidak heran jika Undang-undang yang mendasari berlakunya Perbankan Syariah pada masa-masa awal, yakni UU No. 7 tahun 1992 tentang Perbankan, menyebutkan adanya istilah bank "bagi hasil". ${ }^{21}$

Secara filosofis, akad mudharabah ini relatif menggambarkan keadilan dan keseimbangan antara nasabah (shabibul mal) dengan perbankan syari'ah maupun dengan pihak pengelola (mudharib). Namun banyak hal yang menjadi persoalan teknisnya seperti; (1) apakah dana yang dibagikan antara pengelola (mudharib), bank dan nasabah (shabibul mal) itu merupakan revenue sharing atau profit sharing? (2) mengenai proyek apa yang mungkin dibiayai dengan akad mudharabab ini, sebab secara teknis mudharabah adalah

\footnotetext{
${ }^{21}$ Sutan Remy Sjahdeini, Perbankan Syariab; Produk-produk dan Aspek-aspek Hukumnya, Jakarta: Prenadamedia Group, 2014, hal. 31
} 
akad kerjasama usaha antara dua pihak di mana pihak pertama (shabibul mal) menyediakan seluruh (100\%) modal, sedangkan pihak lainnya menjadi pengelola. $^{22}$

Pembiayaan mudharabah ini bersifat produktif karena diinvestasikan untuk penyediaan modal kerja sehingga dapat memberdayakan perekonomian masyarakat kecil melalui Usaha Mikro, Kecil, dan Menengah (UMKM). Pemberdayaan usaha kecil merupakan salah satu cara untuk membuka lapangan kerja baru yang dapat meningkatkan pendapatan masyarakat dan mengurangi tingkat pengangguran atau kemiskinan. Pembiayaan mudharabah dengan prinsip bagi hasil dapat memberikan dampak yang positif terhadap perkembangan sektor riil, khususnya usaha mikro, kecil dan menengah yang menjadi indikator kemajuan roda perekonomian negara melalui kegiatan investasi. ${ }^{23}$

Argumen rasional dari akad mudharabah adalah bahwa jenis akad ini sangat dibutuhkan oleh manusia. Hal itu disebabkan karena adakalanya seseorang punya modal, tetapi tidak mampu menjalankan modal itu sebagai modal produktif. Pada saat yang sama, ada seseorang yang memiliki kamampuan mengelola dan mengembangkan harta, tetapi dia tidak memiliki modal. Oleh sebab itu, syari'at Islam memberikan jembatan kepada dua pihak yang saling membutuhkan untuk mengikatkan diri dalam suatu akad untuk suatu cita-cita yaitu terciptanya kemaslahatan bersama. Dengan kata lain, landasan filosofis dari akad mudharabah adalah lahirnya hubungan mutualistik antara pemilik modal dan pengelola modal dalam rangka mengembangkan usaha bersama atas dasar saling menguntungkan. Prinsip ta'awun (tolong-menolong) dan saling membutuhkan menjadi pondasi terbangunnya akad kerjasama dalam bidang ekonomi. ${ }^{24}$

Pada prinsipnya, akad mudharabah menjadi jembatan relasi kemanusiaan bidang kerja sama ekonomi atas dasar cinta dan kasih sayang antara para pihak yang terlibat dalam perjanjian, bukan saling memanfaatkan antara satu pihak terhadap pihak yang lain. Akad

\footnotetext{
22 Muhammad Syafi'i Antonio, Bank Syri'ab Wacana Ulama dan Cendekiawan, Jakarta: Tazkia Institut, 1999, hal. 171

${ }^{23}$ Dwi Agung Nugroho Arianto, "Peranan Al-Mudharabah Sebagai Salah Satu Produk Perbankan Syariah Dalam Upaya Mengentaskan Kemiskinan Di Indonesia” Dalam Jurnal Ekonomi \& Pendidikan, Volume 8 Nomor 2, November 2011, hal. 184

24 Ridwan, "Konstruksi filosofis akad-akad ekonomi syariah" dalam Ijtihad, Jurnal Wacana Hukum Islam dan Kemanusiaan Vol. 15, No. 2 (2015), hal. 270
} 
mudharabah akan terjalin manakala kebutuhan para pihak bertemu dalam satu kesepakatan untuk kerjasama ekonomi. Jika ada seseorang mempunyai kelebihan harta dan dia melihat orang lain mempunyai kemampuan untuk mengembangkan, maka pemilik modal dapat melakukan kerjasama dengan orang yang profesional dalam menjalankan usaha untuk kerjasama atas dasar saling menguntungkan. Bagi pemilik modal, dia akan memperoleh keuntungan, pertama pahala dari Allah karena telah memberi ruang bagi orang lain untuk berkembang secara ekonomis dan mengangkat kemiskinan dan masalah ekonomi.

Apabila yang diajak kerjasama adalah orang yang sudah kaya, maka kerjasama mudharabah menjadi media untuk saling tukar pengalaman dan pengetahuan dalam pengembangan usaha. Jika orang yang diajak kerjasama termasuk orang miskin, maka kerjasama dibidang mudharabah memberi ruang bagi pelaksana modal untuk membangun relasi bisnis karena dimensi social trust sudah terbangun. Dasar hukum mudharabab adalah bersumber dari al-Qur'an, Sunnah, Ijma dan Qiyas. Dasar hukum yang bersumber dari al-Qur'an antara lain surat al-Muzammil ayat 20, alJumu'ah ayat 10 dan al-Baqarah ayat 198.

Mudharabah adalah suatu transaksi pembiayaan berdasarkan prinsip syariah yang dilakukan oleh kedua belah pihak berdasarkan asas kepercayaan (trust). Kepercayaan ini merupakan unsur terpenting dalam transaksi pembiayaan mudharabah ini, yakni kepercayaan dari shabibul mal kepada mudharib. Kepercayaan ini merupakan unsur terpenting dalam transaksi mudharabah ini. Oleh sebab itu, sebelumnya terjadinya transaksi mudharabah ini, menurut pandangan penulis, perlu dilakukan pembentukan Sumber Daya manusia (SDM) yang jujur dan trampil dan lingkungan kerja yang saling percaya dan dapat dipercaya. Hal ini tentu membutuhkan langkah-langkah awal yang komprehenship seperti pelatihan 'kejujuran' yang intensif dan berkelanjutan serta pengawasan yang melekat dan setiap saat, sebab hal ini menyangkut trust financing.

\section{F. KESIMPULAN}

Dari uraian tersebut di atas dapat diambil beberapa kesimpulan. Pertama, akad Mudharabah merupakan salah satu akad yang dipergunakan oleh bank syari'ah dalam rangka mengelola pendanaan dan pembiayaannya. Hal ini dilakukan agar kehadiran perbankan Syari'ah secara maksimal dapat menjauhi praktek riba. Kedua, Secara ideal akad mudharabah ini sudah semestinya menjadi produk andalan perbankan 
syari'ah mengingat fokus penekanannya pada kemitraan. Sebab pada prinsipnya dengan kemiraan ini dua pihak yang bertransaksi sama-sama diuntungkan. Ketiga, dalam kenyataannya bank maupun nasabah tidak akan mau untuk berbagai kerugian. Sementara praktek mudharabah memungkinkan untuk hal tersebut. Oleh sebab itu, hal ini dibutuhkan pelatihan dan pendampingan yang intensif terhadap pengelola modal (mudharib) agar dampak kerugian tersebut dapat diminimalisir bahkan diantisipasi. Keempat, dalam rangka menciptakan kepercayaan ketika melakukan transaksi mudharabah ini, maka diperlukan langkah-langkah awal ke arah saling percaya tersebut, seperti melalui pelatihan dan pendampingan yang intensif serta pengawasan yang melekat.

\section{DAFTAR PUSTAKA}

Abidin, Ibnu, Rad al-mukhtar 'ala al-ardh al-mukhtar, Jilid VI, Beirut: Dar alFikr, tanpa tahun

Al-Jaziri, Abdurrahman, Kitab al-Fiqh ala Madzabib al-Arba'ah, Beirut: Dar al-Fikr, tanpa tahun

al-Shabuni, Muhammad Ali, Rawa'I al-Bayan Tafsir Ayat al-Abkam min alQur'an, Jilid I, Beirut: Dar al-Fikr

al-Zuhaily, Wahbah, al-Figh al-Islami wa adillatubu, Juz IV, Beirut: Dar alFikr, 1989

Antonio, Muhammad Syafi'i, Bank Syariab: Dari Teori ke Praktik, Jakarta: Gema Insani, 2001

Antonio, Muhammad Syafi'i, Bank Syari'ah: Wacana Ulama dan Cendekiawan, Jakarta: Tazkia Institut, 1999

Arifin, Zainul, Drs, MBA, Dasar-dasar Managemen Bank Syariah, Jakarta: Alvabet, 2003

Ash-Shiddiqie, Hasbi, Pengantar Fiqh Muamalah, Jakarta: Bilan Bintang, 1984

Departemen Agama RI, Al-Qur'an dan Terjemahannya, Yayasan Penyelenggara Penerjemahan Al-Qur'an, Semarang: CV Toha Putra, 1996

Dwi Agung Nugroho Arianto, "Peranan Al-Mudharabah Sebagai Salah Satu Produk Perbankan Syariah Dalam Upaya Mengentaskan Kemiskinan Di Indonesia" Dalam Jurnal Ekonomi \& Pendidikan, Volume 8 Nomor 2, November 2011

Fachruddin, Fuad Muhammad, Riba dalam Bank, Koperasi dan Asuransi, Bandung: PT Al-Ma'arif, 1985 
Karim, Adiwarman, Ir, SE, MBA, MAEP, bank Islam Analiis Fiqh dan Keuangan, Jakarta: PT RajaGrafindo, 2004

Kasmir, SE, MM, Bank dan Lembaga Keuangan Lainnya, Jakarta: PT RajaGrafindo, 2002

Latifa M. Algaoud dan Mervin K. Lewis, Perbankan Syari'ah Prinsip Praktik Prospek, Jakarta: Serambi Ilmu Semesta, 2005

Lewis, Mervin K. and Latifa M.Algaoud, Islamic Banking, Massachusetts: Edward Elgar, 2001

Mannan, M. Abdul, Prof., M.A, Ph.D, Teori dan Praktek Ekonomi Islam, Yogyakarta: PT. Dana Bhakti Prima Yasa, 1997

Mas'adi, Ghufron A., Drs, M.Ag, Fiqh Muamalah Kontekstual, Jakarta: PT Raja Grafindo Persada, 2002

Muhammad, Drs, M.Ag, Managemen Bank Syariah, Yogyakarta: UPP AMP YKPN, 2002

Muhammad, Drs, M.Ag, Tehnik Perbitungan Bagi Hasil di Bank Syariah, Yogyakarta: UII Press, 2001

Perwataatmadja, Karnaen, Drs. H. MPA, dan HH. Muhammad Syafi'I Antonio, M.Ec, Apa dan Bagaimana Bank Islam, Yogyakarta: PT Dana Bhakti Prima Yasa, 1992

Rahman, Afzalur, Doktrin Ekonomi Islam, Jilid 1,2,3, Jakarta: Dana Bhakti Wakaf, 1995

Ridwan, "Konstruksi filosofis akad-akad ekonomi syariah" dalam Ijtihad, Jurnal Wacana Hukum Islam dan Kemanusiaan Vol. 15, No. 2 tahun 2015

Ridwan, Muhammad, Managemen Baitul Maal Wa Tamwil (BMT), Yoyakarta: UII Press,

Rusyd, Ibnu Bidayatul Mujtahid wa Nihayah al-Muqtashid, Jilid II, Dar al-Fikr, tanpa tahun

Saeed, Abdullah, Bank Islam dan Bunga; Studi Kritis dan Interpretasi Kontemporer tentang Riba dan Bunga, Yogyakarta: Pustaka Pelajar, 2004

Sholahuddin M., SE, M.Si, Lembaga Ekonomi dan Kenangan Islam, Surakarta: Muhammadiyah University Press, 2006

Sinungan, Muchdarsyah, Drs, Managemen Dana Bank, Jakarta: Bumi aksara, 2000

Sjahdeini, Sutan Remy, Perbankan Syariab; Produk-produk dan Aspek-aspek Hukumnya, Jakarta: Kencana Prenadamedia Group, 2014

Sudarsono, Heri, Bank dan Lembaga Kenangan Syariab: Dskripsi dan Ilustrasi, Yogyakarta: Ekonosia, 2003

Suhendi, Hendi, Drs. H. M.Si, Fiqh Muamalah: Membahas Ekonomi Islam, Jakarta: PT Raja Grafindo, 2002 
Sumitro, Warkum, SH, MH, Asas-asas Perbankan Islam dan Lembagalembaga Terkait: BMI dan Takaful di Indonesia, Jakarta: PT Raja Grafindo Persada, 2002

Syafei, Rachmat, Prof. Dr. H. M.A, Fiqh Muamalah, Bandung: Pustaka Setia, 2001

Tadjoedin, Ahmad Ramzy dkk, Berbagai Aspek Ekonomi Islam, Yogyakarta: P3EI bekerjasama dengan Tiara Wacana, 1992

Umar, Hesein, Research Methods in Finance Banking, Jakarta: PT Gramedia Pustaka Utama, 2002

Wirdyaningsih, SH, MH, (ed.), Bank dan Asuransi Islam di Indonesia, Jakarta: Kencana, 2005

Wiroso, SE, MBA, Penghimpunan Dana dan Distribusi Hasil Usaba Bank Syari'ah, Jakarta: PT Grasindo, 2005 